Policy Research Working Paper 1952

Enterprise Isolation Programs in Transition Economies

\section{Simeon Diankov}

Poor results from the isolation program for financially distressed firms in Romania suggest that enterprise restructuring under government atispices does not work - that transition economies shouid privatize rapidly, without attempting first to restructure enterprises.

The World Bank

Finance, Private Sector, and Infrastructure Network Economic Policy Unit August 1998

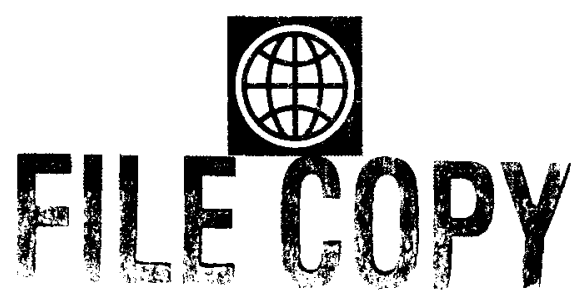




\section{Summary findings}

How should countries in transition to marker economies handle the losses of large loss-making enterprises? Over the past six years several governments in transition economies have implemented isolation programs that combine features of reorganization under bankruptcy (as in industrial countries) with severance payments for employees and assistance with labor deployment.

Djankov analyzes isolation programs for financially distressed firms in transition economies based on empirical evidence from Romania, the program that had the greatest coverage.

The results indicate that Romania's isolation program fulfilled none of its intentions. Despite substantial costs, it neither delivered tangible improvements in operational performance nor improved the process of privatization or liquidation of large loss-making enterprises.
Worse still, the program may have delayed restructuring by not imposing hard budget constraints. Firms included in the program faced softer budget constraints than their counterparts outside the program. Loss makers were not selected through objective criteria, and the agency in charge was not sheltered from political pressure in enforcing hard budget constraints.

Djankov therefore questions the feasibility of creating special programs for enterprise restructuring under government auspices, with government agencies choosing beneficiaries and deciding on the scope of activity.

His conclusion supports the insistence of international donor organizations that governments in transition economies privatize rapidly, without attempting first to restructure enterprises.

This paper - a product of the Economic Policy Unit, Finance, Private Sector, and Infrastructure Network - is part of a larger effort in the network to study transition economies. The study was funded by the Bank's Research Support Budget under the research project "Enterprise Restructuring in Bulgaria and Romania" (RPO 681-96). Copies of this paper are available free from the World Bank, $1818 \mathrm{H}$ Street NW, Washington, DC 20433. Please contact Rose Vo, room MC4-406, telephone 202-473-3722, fax 202-522-2530, Internet address hvo1@worldbank.org. The author may be contacted at sdjankov@worldbank.org. August 1998.(17 pages)

The Policy Research Working Paper Series disseminates the findings of work in progress to encourage the exchange of ideas about development issues. An objective of the series is to get the findings out quickly, even if the presentations are less than fully polished. The papers carry the names of the authors and should be cited accordingly. The findings, interpretations, and conclusions expressed in this paperare entirely those of the author. They do not necessarily represent the view of the World Bank, its Executive Directors, or the countries they represent. 


\title{
Enterprise Isolation Programs In Transition Economies: Evidence from Romania
}

\author{
Simeon Djankov*
}

JEL code: F13; Keywords: Bankruptcy, transition economies, financial discipline

* World Bank. Correspondence: sdjankov@worldbank.org; tel: 202-473-4748. Address: World Bank, 1818H St. NW, Washington DC 20433. I am grateful to John Nellis, Melinda RothAlexandrowicz and Patrick Tardy for helpful suggestions, and Kosali Ilayperuma for excellent research assistance. 


\section{Enterprise Isolation Programs In Transition Economies: \\ Evidence from Romania}

\section{Introduction}

The transition to market has changed fundamentally the relationship between politicians and firms in former centrally-planned economies. In the countries which pursued rapid privatization, the dependence of firms on the state budget has been eliminated. The reform of the banking system has hardened budget constraints on managers who previously enjoyed a close co-operation with their creditors. Governments which have pursued reforms less rigorously, however, still finance the losses of many large state-owned enterprises. This provides fiscal instability, as evidenced in the 1996 banking sector collapse in Bulgaria. What should governments do to alleviate the drain on the state budget? Can this be handled through the nascent court bankruptcy system? Or is it necessary to create special programs targeted at the largest loss-makers? Given the large number of loss-making enterprises in transition economies, no previous comparable experience exists to provide guidelines for state involvement.

Over the last six years, several governments in transition economies have implemented isolation programs for large loss-making state-owned enterprises. Theoretically, isolation programs combine features of reorganization under bankruptcy as developed in industrialized countries, ${ }^{1}$ with severance payments for employees and labor deployment assistance. In this paper, I provide the first empirical evidence on the results of the Romanian isolation program. I choose to study the Romanian program since it had the widest coverage. I also have financial statements for all firms included in the program, as well as extensive case-study materials prepared by foreign consultants. The results indicate that the isolation program did not deliver any tangible improvements in operational performance, nor did it enhance the process of privatization and liquidation of large loss-making enterprises. I also show that firms included in the program faced softer budget constraints than their comparators outside the program through access to special funds and continued government subsidies. These findings question the feasibility of creating special programs for enterprise restructuring and privatization under government auspices.

The rest of the paper is organized as follows. Section II details the objectives and components of the programs implemented in seven transition economies. Section III summarizes the Romanian program. Section IV describes the data and provides

\footnotetext{
1 The two differ significantly, however, in that isolation programs also aim at changing the ownership of surviving firms through privatization. In this respect the only precedent to the isolation programs is the East German Treuhandanstalt which existed between 1990 and 1995 with the principal task of privatizing or liquidating over 8,000 state-owned firms, including two hundred large loss-makers. For evidence on the Treuhandanstalt, see Carlin and Mayer (1992) and Priewe (1993).
} 
descriptive statistics. Sections V provides rigorous empirical analysis. Section VI concludes.

\section{Isolation Programs in Transition Economies}

The rationale for isolation programs in transition economies is based on the belief that the emerging bankruptcy system cannot handle the large number of loss-makers expediently ${ }^{2}$ so as to prevent a drain on the state budget and an associated collapse of the banking sector. Countries where such programs were not put in place (Czech Republic, Hungary, Estonia, Poland) arguably had good institutional environment, had privatized quickly, and had more stable banking systems. Three additional reasons make isolation programs attractive to politicians. First, transition economies inherited an industrial structure characterized by large firms that frequently employ all of a town's working population and provide many social services (heating, schools, hospitals). Closing such firms would leave employees with few outside options and may cause political upheaval. Second, more transparency in financing loss-makers is achieved, even if firms are still supported through state funds. Third, downsizing is made easier if all social services are placed in the hands of the state, and severance pay for workers is provided.

Isolation programs were implemented in seven transition economies - Albania, Armenia, Bulgaria, Kazakstan, the Kyrgyz Republic, Macedonia, and Romania. The programs were designed to cover large loss-making state-owned enterprises. While there were some variations across countries in the number of firms and their selection, all programs had similar objectives. First, the program would force managers of firms to reduce operational losses without external financial support, to the point where these firms would generate a positive cash flow. Second, the program would ensure that firms' losses were not financed through building up arrears to banks, to suppliers, to the state budget, and the social security fund. Third, it would introduce transparency in government policy by forcing explicit decisions on budgetary support for loss-making enterprises; and policies designed to minimize the social impact of reorganization. Fourth, the program would

\footnotetext{
${ }^{2}$ Two recent studies analyze the evidence on bankruptcy outcomes in transition economies. Gray and Holle (1997) argue that the Polish bankruptcy law has several deficiencies. First, only firms which have sufficient assets to cover procedural costs can have their reorganization plans confirmed. This creates a loophole for managers - if the firm shows negative net assets, it is automatically excluded. Second, the order of claimants' preferences reduces the incentive for bank creditors to initiate bankruptcy since the first claimant is the government, the second the employees; only when their claims are satisfied can other parties partake in the distribution of assets. Finally, creditors who initiate the bankruptcy procedure are asked to pay up to $13 \%$ of the value of their claims as advance payment of court fees. For the 23 bankruptcy cases covered by the study, creditors recovered only between $7 \%$ to $17 \%$ of their claims. The procedure also lasted 41 months on average. Gray et al (1996) study the Hungarian bankruptcy experience. They conclude that the bankruptcy procedures "did little to further either deep restructuring or the exit of ailing firms". Of the fifty firms slated for liquidation, only one was closed down within two years after the initiation of liquidation.
} 
place the responsibility of restoring financial discipline with the firms' management. Fifth, the implementation of such a program would send a signal to other state-owned firms that the imposition of hard budget constraints was closely monitored and there would be penalties for failure to pursue reorganization.

While under isolation, all overdue debts are frozen until conciliation agreements with all creditors are concluded. Arrears on wages are only paid when firms have generated internally cash to pay its employees. Once firms negotiate conciliation agreements, they can have some of their debt written off, rescheduled, or swapped for equity. If a firm has not reached positive cash flow at the end of the isolation exercise, it should be liquidated or privatized. To alleviate the pressure in shedding access labor, most programs offered severance packages for workers. Managers could use this source to provide up to twelve months of wages to employees who would leave voluntarily. The money could also be used for re-training and relocation of workers.

An additional feature of the programs was the establishment of a monitoring unit which tracked the financial and operational performance of each firm on a monthly basis. The unit could be part of the newly created agencies for restructuring (as in Romania, Albania, Armenia, the Kyrgyz Republic), or be based in the Ministry of Finance (Bulgaria, Macedonia, Kazakstan). The isolation programs were time-bound - designed to last for two to four years. This prevented their "institutionalization", i.e., turning them into staterun ministries which carried out industrial strategies. Beyond the program, any firm that was failing should go through the court bankruptcy procedures. The burden to take such firms to court would be on their creditors and not the government. ${ }^{3}$

\section{Description of the Romanian Program}

In 1992 the Romanian government required a group of loss-making firms to design diagnostic reports of their financial situation and operational performance. The Agency for Restructuring (AR) was founded the following year with the principal task of reorganizing troubled firms which would be sheltered from their creditors, and would receive technical as well as financial assistance in restructuring their business. The structure included not only the AR (under the Council for Coordination, Strategy and Economic Reform) but also the State Ownership Fund, and the branch ministries responsible for utility firms. Initially about 300 loss makers (accounting for $70 \%$ of total enterprise losses) were targeted. Under union pressure, however, the government dropped many firms off the list. Only 73 firms remained in the final draft (April 1994). In November 1994, another 74 agricultural farms were added to the program. The total number of firms increased to 147 . While the AR had control over most commercial

3 The Romanian bankruptcy law (1995) is fashioned after the German law which is creditor-friendly. Banks and the state may take a firm to court if payments have been in arrears for a specified length of time. Once the firm files for bankruptcy, an outside trustee is appointed to make decisions (including whether to reorganize or liquidate). Sanctions for delay in filing are imposed. 
companies and agricultural farms, the State Ownership Fund was given control over 31 commercial companies, while nine utilities (power, transport, gas) were controlled by the respective branch ministries. The latter was deemed necessary as utility companies could not be privatized or liquidated by law, and their employees enjoyed special status. The selection resulted in having only 4 of the largest 10 loss-makers, 46 of the largest 100 lossmakers, and 82 of the largest 300 loss-makers among the state-owned enterprises under isolation. The program was thus deficient from its inception as it failed to cover many of the worst firms - beneficiaries of state funds. This resulted partly from the way it was perceived by managers - as an enterprise 'sanatorium' rather than a 'jail'. Firms were eager to join the program because this would give them access to further sources of state funds.

All firms in the reorganization program were required to design financial recovery plans with technical assistance provided by foreign consultants. Recovery plans focused on short term steps to reduce expenses. The format included proposed restructuring strategy and expected financial impact of each action as well as detailed profit forecasts. Firms should be able to recover operating finances through simple cash managementtracing where the money was lost, who owed them money - and collecting these receivables diligently. The financial plans had limited success. Managers were reluctant to take measures unpopular with the workers because they were either elected directly by workers, or else their appointment was approved by the union. An additional weakness was the lack of managerial knowledge. Managers were unable to assess their firms' financial status because no attention was paid to such details in their previous work. When assessing profits, they treated subsidies and production for inventories as revenues. At the opposite end, when a firm produced goods for its own consumption, they were not counted as revenues. Not surprisingly, only five of the initial 73 firms suggested measures to cut back production. The remaining 68 charted expansionary strategies based on investment and entry into new markets, even though demand for their products was rapidly falling.

The State Ownership Fund was allowed to lend money to enterprises under isolation through a special Structural Fund. The Structural Fund was set up to finance (i) operating subsidies allocated by the government; (ii) working capital to meet export orders; and (iii) redundancy payments to employees. The Fund allowed (in theory) for transparent allocation of public money to loss-making firms. Any infringement on the rules would result in the dismissal of the management team. The Romanian Enterprise Restructuring Ordinance, for example, stated that "failure to observe measures stipulated by the programs for restructuring and financial rehabilitation within the period established, results in the revocation of manager and the replacement of the Administration Council members in the case of state companies and in the revocation of managers in case of the commercial companies." Redundancy payments were equal to 6 months of pay. This made it easier to downsize the labor force. For firms that were too politically important to be shut down, this fund also helped pay their utility bills in a transparent way. It introduced, however, a softer budget constraint. Firms under isolation gained access to extra funds, not available to enterprises outside the program. 
At the time of closing the program (February 1997), only four firms had "graduated": two were privatized in 1996, while another two were liquidated. Another 13 enterprises from the program were closed down by the new government in August, 1997. This closure was not related to the isolation program, as some other companies (not on the isolation list) were also closed. The program did not have a significant impact on managerial turnover: during the implementation of the program only seven (of 147) CEOs were fired. Although these outcomes were hardly what the architects of the isolation program had in mind, perhaps the program was effective in operational turn-around and eliminating the dependency of isolated firms on the state budget. We consider the empirical evidence in the following sections.

\section{The Data}

I have firm-level data (balance sheet and profit and loss statements) for 1992-96 obtained from the Romanian Statistical Office. The data are annual observations and cover all firms which were registered as state-owned enterprises in 1992. If some plants are owned by the same parent company, this relationship is accounted for in the data. Overall, more than 8,000 enterprises are included. From those, I select two groups of firms. The first set contains 146 firms from the isolation program, identified by firm numbers - one utility company was excluded from the study for lack of accounting data. The second set contains a control group of 146 firms, matched one for one with enterprises in the isolation group. Within each sector, I chose firms in the control group which had the most similar size (measured by number of employees), profitability, and subsidies (as measured by their share in total revenues) in 1992 to corresponding firms in the isolation program. Firms come from nine sectors. This algorithm resulted in a distribution of firms across sectors (Table 1) which is identical between the focus and control groups. The large share of agricultural firms is due to the inclusion of pig and poultry farms in the reorganization program in 1994. Although numerous, these firms do not account for a large part of overall employment. The largest firms are to be found in coal mining and utility sectors.

International accounting standards were not introduced in Romania during the sample period. This is not a problem in the analysis here which compares relative performance across groups of firms in the same year (period). Several adjustments were made, however. Under the Romanian accounting system, for example, subsidies and production for inventories are counted as sales. Since data on sales, subsidies, and inventory changes are reported in all cases, I recalculate the revenue numbers to account for sold (rather than produced) output. Firm-specific output prices are not available. One option is to use output price indices at the industry level. This, however, limits the comparisons between firms within the same sector, given the likely variation in their pricing strategies. I hence develop the analysis on the basis of ratios of revenues and 
financing, thus avoiding the need for inflation-accounting, i.e. I use nominal data in both the numerator and denominator.

I choose as indicators of enterprise restructuring improvements in profitability, labor shedding, reductions in the debt-to-assets ratio, and reductions in subsidies and inventories relative to sales revenue. The first two proxy for operational performance changes, while the latter three track hardening of budget constraints. Table 2 presents means, medians and standard deviations of key variables in the isolated and control groups. Sector-specific statistics are reported in Table 1A. Isolated enterprises in the agricultural sector show rapid deterioration in all five indicators relative to control group firms, while isolated enterprises in the non-metallic products sector show a relative improvement. Isolated enterprises in the other seven sectors also show deteriorated performance relative to their comparators, although this trend is less uniform.

I first consider the two indicators of operational performance. Profitability (defined as sales minus wages minus materials expenses over sales) was similar across firms in the two groups in $1992--0.055$ and -0.023 for the focus and control group respectively. By 1996, however, isolated enterprises displayed a rapidly worsening profitability - the ratio declined to -0.358 , while control group firms showed only a slight deterioration in performance. Between 1992 and 1996, enterprises under isolation reduced their employment by $17.1 \%$, while firms in the control group by $24.1 \%$. This difference may be due to firm size - firms in the isolation program were somewhat larger than firms in the control group. This argument can only be supported if there exists some rationale for having more constraints to employee reductions in larger firms, e.g., the role of plant-specific labor unions. Since labor unions in Romania are industry-specific, not plant-specific, the difference in labor shedding should not be associated with plant size. I next exclude the Utilities sector which accounts for much of the difference in size. The difference in labor shedding between the two groups remains about the same $-15.4 \%$ and $28.3 \%$ over the $1992-96$ period.

Next I study the three indicators of financial restructuring. Indebtedness (measured by total debt to assets ratio) increased by a third between 1992 and 1996 (from 0.223 to 0.295 ) for firms in the isolation program. Control group firms experienced similar deterioration over the sample period $(0.206$ to 0.262$)$. I chose total debt as the numeraire since bank credit was not the major source of financing to loss making firms. Another financing source was to delay payment for inputs. Overdue payments to suppliers constitute about $70 \%$ of all overdue payments, falling from $73 \%$ in 1992 to $58 \%$ in 1996 (not reported in Table 2). This suggests that suppliers, not banks, might be source of the soft budget constraint. Anecdotal evidence suggests that many firms built up arrears to their energy suppliers-the electric utilities in particular. Utilities in turn built up arrears with their suppliers, the coal mines. Mines were not, however, the ultimate loser, since they enjoyed significant subsidies through the state budget. 
Direct subsidies from the budget increased slightly - from 0.054 to 0.077 for isolated enterprises; and from 0.017 to 0.026 for firms in the control group. In addition, isolated firms received structural funds not available to control group firms to the amount of 0.037 and 0.053 of revenues in 1995 and 1996 respectively. Thus, transfers from the budget for isolated firms increased from $5.4 \%$ of total revenues in 1992 to close to $12 \%$ by 1996 . The continuing deterioration in financial performance can be seen in the inventory to sales ratio that increased threefold in the sample period for firms in the isolation program - from 0.113 to 0.324 . Firms in the control group also registered increased inventory build-up albeit to a lesser degree - from 0.114 to 0.257 .

These simple descriptive statistics suggest that the isolation program did not result in improved operational or financial performance. Nor did it eliminate (or even curb) access to state funds. Since these observations are not based on econometric analysis, they may be misleading. In particular, the observed trend may be endogenous - if the Romanian government selected (with perfect foresight) the worst loss-makers into the program, the results on operational performance would be less surprising. This is unlikely, however, since less than half of the worst performing enterprises were included in the programs. The statistics also show lack of hardened budget constraint for enterprises in the isolation group. I perform some additional regression analysis in the next section.

\section{Evidence}

The description of the Romanian isolation programs in Section III suggests that it was adopted with three specific objectives in mind. In particular, the program was expected to bring (1) reduced operational losses to the isolated firms; (2) reductions in excess employment; and (3) a reduction in government funds allocated to loss-making enterprises. In this section I test if these objectives were achieved.

The sample selection criteria outlined in Section IV allows me to test whether the performance of firms changed after inclusion in the program. I employ a matched pair methodology for comparing pre- and post-inclusion performance of firms. I also compare the performance of firms in the isolation program with firms outside the program which otherwise had similar characteristics. In both cases, I use the Wilcoxon signed-ranked test as the principal method for hypothesis-testing. ${ }^{4}$ If significant changes in the behavior of firms under isolation did take place, one would expect to see improved performance both over time and as compared to the control group of firms that did not participate in the program. Since the two groups are of identical size, I can interpret the magnitudes of the $Z$-statistics as evidence for smaller (larger) changes in performance.

\footnotetext{
${ }^{4}$ One alternative method to compare changes over time and between the two groups is to perform $\mathrm{T}$ tests on select performance indicators. This approach, however, is inefficient when a large degree of variation (represented by high standard deviations of indicators) exists in the sample. I also performed regression analysis on the main indicators of firm performance (profitability, employment changes). Since the results are qualitatively similar to the findings using Wilcoxon sign tests -- no differences were found in firm behavior in the focus and control groups -- they are not reported here.
} 
Table 3, Panel A looks at differences across time of enterprises by sector for the control and isolated groups separately. The differences are calculated using 1996 performance as a benchmark. A negative $Z$-statistics on employment, for example, would mean that the firms have reduced employment between 1992 and 1996. A positive sign on profitability would indicate that firms improved their performance during 1992-96. Finally, a negative sign on subsidies would indicate hardened budget constraints. In all cases, the coefficients are statistically significant if they are above 1.96 in absolute magnitude. Since agriculture constitutes about half the sample for both sets of firms, it is possible that it drives the overall result. I hence also run the Wilcoxon Test on all sectors excluding agriculture. The results are reported in the next to last row of Table 3, Panel A.

Across sectors, in both the control and the isolation groups, the Wilcoxon test statistics indicate that employment was reduced significantly between 1992 and 1996 . The largest reductions occurred in agriculture - Z-stat of -3.485 and -7.113 for the isolated and control groups respectively. Although the isolation program resulted in labor shedding, I show that more drastic labor shedding took place in firms outside the program, despite their lack of access to redundancy payments. Profitability went down for both groups: $Z$ stats of -4.072 and -0.301 respectively. This decline was driven primarily by the worsening of the agricultural sector. Once agricultural farms were excluded, profitability in both groups actually increased (Z-statistics of 2.148 and 2.718 for isolated and control groups). Significant positive improvements in profitability were recorded in three manufacturing sectors (Non-Metallic Products; Chemicals; Metallurgy) in both groups. This is indicative of strong industry effects. Subsidies were cut in all sectors with the exception of agriculture. Again, control group firms were cut off from subsidies more than their comparators under isolation - the respective Z-stats are -5.127 and -8.448 .

Panel A compares firm performance in 1996 (the "after" performance) to the "before" performance in 1992. An alternative method for evaluating performance would be to compare matched pairs from the isolation and control groups (Panel B). A Wilcoxon test statistics were computed for the difference in characteristics between pairwise matched isolation and control group firms in 1992 and 1996. The 1992 comparison shows that the matching procedure managed to pair firms well. As in Panel A, I use a separate test on all sectors excluding agriculture. In the last column, I also add structural funds and subsidies given to isolated firms together to get the total amount of budgetary transfers to enterprises in the program.

The results in Panel B suggest that isolated enterprises saw a deterioration in their performance relative to their matched comparators. Relative to 1992 , the situation in 1996 reflects an improvement for the control group in all aspects. In particular, isolated firms retained higher employment - Z-stats of 4.980 in 1996 as compared to 2.662 in 1992; became less profitable - Z-stats of -4.679 in 1996 as compared to -1.642 in 1992; and received more budgetary transfers - Z-stats of 10.524 in 1996 as compared to 7.809 in 1992. The overall results in all indicators are driven by the inclusion of agriculture. Once 
this sector is excluded, the 1992 and 1996 differences between the two groups become insignificant (the Z-statistics between 1992 and 1996 are about the same). ${ }^{5}$

\section{Conclusions}

I analyze the relative performance of firms selected into the Romanian isolation program. The empirical evidence shows that none of the intentions of the isolation program were fulfilled. Worse still, the program may have delayed restructuring by not imposing hardened budget constraint on loss-making enterprises. The difficulties that the isolation program faced were due to the selection of enterprises into the program and its subsequent implementation. Loss makers were not selected on objective criteria, and the agency in charge was not sheltered from political pressure in enforcing hardened budget constraints.

On a more general level, the evidence in this paper questions the feasibility of designing programs in which government agencies can decide on the scope of activity and selection of beneficiaries. This conclusion is supportive of the insistence of international donor organizations that governments in transition economies privatize rapidly, and not attempt to restructure enterprises prior to privatization.

\footnotetext{
${ }^{5}$ While the isolation program changed little in terms of operational performance or drain on the state budget, its implementation resulted in substantial costs. The operational losses covered by new government subsidies or loans amount to the equivalent of 23 months of wages for all workers in isolated firms; the costs of maintaining the program amount to the equivalent of 5 months of wages; the cost of technical assistance and consulting services amounts to an addition amount of 4 months of wages. Thus the total opportunity cost of the Romanian isolation program can be approximated to 32 months of wages for all workers.
} 


\section{References}

Carlin, Wendy and Colin Mayer. 1992. "Restructuring Enterprises in Eastern Europe," Economic Policy, 15: 312-352.

Gray, Cheryl, Sabine Schlorke, and Miklos Szanyi. 1996. "Hungary's Bankruptcy Experience, 1992-93", World Bank Economic Review, 10: 425-450.

Gray, Cheryl and Arnold Holle. 1997. "Bank-led Restructuring in Poland (II): Bankruptcy and Its Alternatives," Economics of Transition, 5: 25-44.

Priewe, Jan. 1993. "Privatization of the Industrial Sector: the Function and Activities of the Treuhandanstalt," Cambridge Journal of Economics, 17: 333-348. 
Table 1: Sample Statistics, 1992

\begin{tabular}{|c|c|c|c|c|c|c|c|c|c|c|c|c|}
\hline \multirow{3}{*}{ SECTOR } & \multicolumn{6}{|c|}{ Isolated Enterprises } & \multicolumn{6}{|c|}{ Control Group } \\
\hline & \multicolumn{2}{|c|}{ Firms } & \multicolumn{2}{|c|}{ Employment } & \multicolumn{2}{|c|}{ Sales Revenues* } & \multicolumn{2}{|c|}{ Firms } & \multicolumn{2}{|c|}{ Employment } & \multicolumn{2}{|c|}{ Sales Revenues ${ }^{*}$} \\
\hline & Number & $\%$ & Number & $\%$ & Value & $\%$ & Number & $\%$ & Number & $\%$ & Value & $\%$ \\
\hline Agriculture & 70 & 47.95 & 49,703 & 5.70 & 719.00 & 9.09 & 70 & 47.95 & 38,343 & 7.82 & 148.64 & 6.16 \\
\hline Coal and Petroleum & 5 & 3.42 & 192,419 & 21.65 & $2,090.00$ & 26.42 & 5 & 3.42 & 138,285 & 28.23 & 555.94 & 23.01 \\
\hline Food and Beverage & 4 & 2.74 & 3,278 & 0.37 & 17.22 & 0.22 & 4 & 2.74 & 3,699 & 0.82 & 15.63 & 0.65 \\
\hline Non-metallic Products & 14 & 9.59 & 62,461 & 7.03 & 909.86 & 11.50 & 14 & 9.59 & 44,839 & 9.16 & 395.62 & 16.37 \\
\hline Chemicals & 12 & 8.22 & 39,267 & 4.42 & 320.81 & 4.06 & 12 & 8.22 & 38,811 & 7.92 & 391.23 & 16.19 \\
\hline Metallurgy & 12 & 8.22 & 103,255 & 11.62 & $1,057.49$ & 13.37 & 12 & 8.22 & 84,315 & 17.21 & 408.66 & 16.91 \\
\hline Machines and Equipment & 19 & 13.01 & 91,598 & 10.31 & 294.42 & 3.72 & 19 & 13.01 & 82,330 & 16.81 & 176.78 & 7.32 \\
\hline Road Transport & 6 & 4.11 & 49,026 & 5.52 & 177.65 & 2.25 & 6 & 4.11 & 40,669 & 8.32 & 266.34 & 11.02 \\
\hline Utilities & 4 & 2.74 & 296,801 & 33.39 & $2,323.70$ & 29.38 & 4 & 2.74 & 18,630 & 3.81 & 58.27 & 2.41 \\
\hline All & 146 & 100.00 & 887,808 & 100.00 & $7,910.34$ & 100.00 & 146 & 100.00 & 489,921 & 100.00 & $2,416.49$ & 100.00 \\
\hline
\end{tabular}

* In billion Romanian lei. 
Table 2: Comparison of Mean Values

(Mean, Median, Standard Deviation)

\begin{tabular}{|c|c|c|c|c|c|c|c|c|}
\hline \multirow{3}{*}{ Indicator } & \multicolumn{4}{|c|}{ All Firms (146 Observations Each) } & \multicolumn{4}{|c|}{ Excluding Unilities and Road Transport } \\
\hline & \multicolumn{2}{|c|}{ Isolated Enterprises } & \multicolumn{2}{|c|}{ Control Group } & \multicolumn{2}{|c|}{ Isolated Enterprises } & \multicolumn{2}{|c|}{ Control Group } \\
\hline & 1992 & 1996 & 1992 & 1996 & 1992 & 1996 & 1992 & 1996 \\
\hline \multirow[t]{3}{*}{ Profitability } & -0.055 & -0.358 & -0.023 & -0.086 & -0.079 & -0.434 & -0.031 & -0.079 \\
\hline & 0.019 & -0.117 & 0.036 & 0.017 & 0.022 & -0.122 & 0.041 & 0.017 \\
\hline & 0.331 & 0.618 & 0.296 & 0.405 & 0.434 & 0.742 & 0.307 & 0.392 \\
\hline \multirow[t]{3}{*}{ Employment } & 6331 & 5252 & 3752 & 2848 & 4134 & 3498 & 3581 & 2567 \\
\hline & 1598 & 1099 & 1426 & 743 & 1151 & 927 & 1244 & 661 \\
\hline & 19504 & 15982 & 8176 & 6599 & 8639 & 8302 & 8317 & 6344 \\
\hline \multirow[t]{3}{*}{ Debt to Asset Ratio } & 0.223 & 0.295 & 0.206 & 0.262 & 0.219 & 0.301 & 0.205 & 0.268 \\
\hline & 0.200 & 0.257 & 0.179 & 0.224 & 0.203 & 0.267 & 0.183 & 0.241 \\
\hline & 0.128 & 0.153 & 0.117 & 0.199 & 0.134 & 0.152 & 0.121 & 0.202 \\
\hline Subsidies to Sales & 0.054 & 0.077 & 0.017 & 0.030 & 0.054 & 0.076 & 0.013 & 0.026 \\
\hline \multirow[t]{2}{*}{ Ratio* $^{*}$} & 0.000 & 0.001 & 0.000 & 0.000 & $0.000^{\prime}$ & 0.004 & 0.000 & 0.000 \\
\hline & 0.091 & 0.119 & 0.068 & 0.082 & 0.088 & 0.111 & 0.056 & 0.065 \\
\hline Inventory to Sales & 0.113 & 0.324 & 0.114 & 0.257 & 0.134 & 0.354 & 0.122 & 0.2262 \\
\hline \multirow[t]{2}{*}{ Ratio } & 0.027 & 0.204 & 0.036 & 0.162 & 0.028 & 0.203 & 0.044 & 0.167 \\
\hline & 0.214 & 0.367 & 0.202 & 0.306 & 0.316 & 0.406 & 0.202 & 0.308 \\
\hline
\end{tabular}

Notes: * Excluding structural funds for isolated enterprises. 
Table 3: Comparison of Performance Changes, 1992-96*

\begin{tabular}{|c|c|c|c|c|c|c|}
\hline \multirow{3}{*}{$\begin{array}{l}\text { SECTOR } \\
\end{array}$} & \multicolumn{6}{|c|}{ Panel A. Comparison over Time within Each Group (Z Statistics using a Wilcoxon Signed Ranked Test) } \\
\hline & \multicolumn{3}{|c|}{ Changes for Isolated Enterprises, 1992-96** } & \multicolumn{3}{|c|}{ Changes for Control Group, 1992-96** } \\
\hline & Employment & Profitability & Subsidies & Employment & Profitability & Subsidies \\
\hline Agriculture & -3.485 & -6.633 & 4.861 & -7.113 & -3.128 & -6.342 \\
\hline Coal and Petroleum & -0.944 & -0.944 & -1.213 & -1.753 & -1.213 & -2.023 \\
\hline Food and Beverage & -1.826 & -0.731 & 0.731 & -1.826 & -0.365 & -0.367 \\
\hline Non-Metallic Products & -2.919 & 1.977 & -3.290 & -2.981 & 2.668 & -3.296 \\
\hline Chemicals & -3.059 & 2.510 & -1.412 & -2.903 & 2.588 & -0.476 \\
\hline Metallurgy & -2.981 & 2.197 & -3.059 & -3.059 & 2.510 & -3.059 \\
\hline Machinery and Equipment & -3.461 & 0.885 & -3.823 & -3.823 & 0.885 & -3.823 \\
\hline Road Transport & -2.201 & -0.314 & -2.201 & -0.943 & -1.782 & -2.201 \\
\hline Utilities & -0.730 & -1.095 & 0.000 & -0.365 & -0.365 & -0.732 \\
\hline Excluding Agriculture & -6.549 & 2.148 & -3.422 & -6.580 & 2.718 & -5.679 \\
\hline All Enterprises & -7.594 & -4.072 & -5.127 & -9.562 & -0.301 & -8.448 \\
\hline
\end{tabular}

Panel B. Comparison between the Isolation and Control Groups (Z Statistics using a Wilcoxon Signed Ranked Test for Matched Pairs of Firms)

\begin{tabular}{|c|c|c|c|c|c|c|c|}
\hline & \multicolumn{3}{|c|}{ Differences between Means, $1992 * * *$} & \multicolumn{4}{|c|}{$\begin{array}{l}\text { Differences between Means, 1996*** } \\
\text { (The second Subsidies column includes structural funds) }\end{array}$} \\
\hline & Employment & Profitability & Subsidies & Employment & Profitability & Subs & sidies \\
\hline Agriculture & 1.766 & -1.103 & 5.898 & 4.901 & -4.552 & 5.047 & 11.124 \\
\hline Coal and Petroleum & 1.483 & 0.535 & 0.535 & 1.483 & -0.405 & 1.214 & 2.314 \\
\hline Food and Beverage & -0.730 & 0.783 & 0.535 & -0.365 & -1.095 & 1.826 & 2.476 \\
\hline Non-Metallic Products & 1.601 & -1.363 & 3.180 & 1.475 & -0.220 & 2.417 & 3.765 \\
\hline Chemicals & -0.078 & -0.392 & 1.647 & -1.961 & -0.078 & 2.118 & 2.889 \\
\hline Metallurgy & 2.275 & -0.314 & 3.059 & 2.353 & -1.726 & 2.122 & 2.441 \\
\hline Machinery and Equipment & 2.455 & -1.167 & 3.823 & 2.696 & -0.845 & 2.334 & 2.875 \\
\hline Road Transport & 0.105 & -1.082 & 2.201 & -0.105 & 0.734 & 0.314 & 1.096 \\
\hline Utilities & 1.826 & 0.365 & 0.365 & 1.826 & -0.365 & 0.730 & 1.435 \\
\hline Excluding Agriculture & 4.044 & -1.357 & 5.499 & 3.479 & -1.434 & 4.623 & 1.987 \\
\hline All Enterprises & 2.662 & -1.642 & 7.809 & 4.980 & -4.679 & 6.511 & 10.524 \\
\hline
\end{tabular}

Notes: * The cut-off point of significance at the $95 \%$ level for Z-stats is $1.96 * * 1992$ taken as the benchmark; *** Control Group taken as the benchmark. 
Table 1A: By-Sector Comparisons

(Mean, Median, Standard Deviation)

\begin{tabular}{|c|c|c|c|c|c|c|c|c|c|c|c|c|}
\hline & \multicolumn{2}{|c|}{ Isolated Enterprises } & \multicolumn{2}{|c|}{ Control Group } & \multicolumn{2}{|c|}{ Isolated Enterprises } & \multicolumn{2}{|c|}{ Control Group } & \multicolumn{2}{|c|}{ Isolated Enterprises } & \multicolumn{2}{|c|}{ Control Group } \\
\hline & 1992 & 1996 & 1992 & 1996 & 1992 & 1996 & 1992 & 1996 & 1992 & 1996 & 1992 & 1996 \\
\hline & \multicolumn{4}{|c|}{ Agriculture } & \multicolumn{4}{|c|}{ Coal and Petroleum } & \multicolumn{4}{|c|}{ Food and Beverage } \\
\hline \multirow[t]{3}{*}{ Profitability } & 0.048 & -0.632 & 0.094 & -0.112 & 0.047 & -0.309 & 0.008 & -0.294 & -0.314 & -0.692 & -0.168 & -0.207 \\
\hline & $(0.116)$ & $-(0.433)$ & $(0.113)$ & $(0.008)$ & $(0.090)$ & $(0.178)$ & $(0.045)$ & $(-0.087)$ & $(-0.300)$ & $-(0.925)$ & $(-0.304)$ & $-(0.159)$ \\
\hline & 0.308 & 0.693 & 0.245 & 0.433 & 0.425 & 0.962 & 0.204 & 0.875 & 0.562 & 0.557 & 0.369 & 0.578 \\
\hline \multirow[t]{3}{*}{ Employment } & 736 & 667 & 613 & 345 & 38097 & 36265 & 29621 & 24349 & 849 & 536 & 1008 & 624 \\
\hline & $(518)$ & $(415)$ & $(451)$ & $(222)$ & (33124) & $(27312)$ & $(29500)$ & $(21460)$ & $(686)$ & $(408)$ & $(446)$ & (381) \\
\hline & 1152 & 1012 & 483 & 337 & 18971 & 19816 & 13879 & 14155 & 712 & 430 & 1202 & 604 \\
\hline \multirow[t]{3}{*}{ Debt to Asset Ratio } & 0.250 & 334 & 0.186 & 0.264 & 0.178 & 0.246 & 0.179 & 0.336 & 0.432 & 0.319 & 0.276 & 0.196 \\
\hline & $(0.227)$ & $\therefore 287$ ) & $(0.165)$ & $(0.217)$ & $(0.162)$ & $(0.235)$ & $(0.163)$ & $(0.294)$ & $(0.284)$ & $(0.286)$ & $(0.296)$ & $(0.211)$ \\
\hline & 0.13 & $\ldots 8$ & 0.131 & 0.253 & 0.081 & 0.135 & 0.091 & 0.162 & 0.389 & 0.150 & 0.104 & 0.097 \\
\hline Subsidies to Sales & 0.0 & 0.122 & 0.008 & 0.044 & 0.171 & 0.267 & 0.067 & 0.106 & 0.112 & 0.068 & 0.073 & 0.001 \\
\hline \multirow[t]{2}{*}{ Ratio } & $(0.034 ;$ & $(0.112)$ & $(0.000)$ & $(0.025)$ & $(0.070)$ & $(0.072)$ & $(0.000)$ & $(0.000)$ & $(0.114)$ & $(0.070)$ & $(0.000)$ & $(0.000)$ \\
\hline & 0.067 & 0.085 & 0.028 & 0.063 & 0.192 & 0.339 & 0.152 & 0.233 & 0.105 & 0.048 & 0.142 & 0.002 \\
\hline Inventory to Sales & 0.041 & 0.471 & 0.051 & 0.337 & 0.051 & 0.082 & 0.054 & 0.144 & 0.263 & 0.315 & 0.309 & 0.296 \\
\hline \multirow[t]{2}{*}{ Ratio } & $(0.004)$ & $(0.288)$ & $(0.000)$ & $(0.189)$ & $(0.050)$ & $(0.026)$ & $(0.028)$ & $(0.047)$ & $(0.026)$ & $(0.297)$ & $(0.148)$ & $(0.284)$ \\
\hline & 0.169 & 0.448 & 0.178 & 0.384 & 0.054 & 0.144 & 0.062 & 0.346 & 0.495 & 0.330 & 0.436 & 0.306 \\
\hline
\end{tabular}

(continued) 


\begin{tabular}{|c|c|c|c|c|c|c|c|c|c|c|c|c|}
\hline & \multicolumn{2}{|c|}{ Isolated Enterprises } & \multicolumn{2}{|c|}{ Control group } & \multicolumn{2}{|c|}{ Isolated Enterprises } & \multicolumn{2}{|c|}{ Control group } & \multicolumn{2}{|c|}{ Isolated Enterprises } & \multicolumn{2}{|c|}{ Control group } \\
\hline & 1992 & 1996 & 1992 & 1996 & 1992 & 1996 & 1992 & 1996 & 1992 & 1996 & 1992 & 1996 \\
\hline & \multicolumn{4}{|c|}{ Non-Metallic products } & \multicolumn{4}{|c|}{ Chemicals } & \multicolumn{4}{|c|}{ Metallurgy } \\
\hline \multirow[t]{3}{*}{ Profitability } & -0.258 & -0.061 & -0.291 & -0.086 & -0.050 & 0.038 & -0.058 & 0.056 & -0.302 & -0.083 & -0.248 & 0.033 \\
\hline & $-(0.258)$ & $(0.025)$ & $-(0.246)$ & $(0.029)$ & $-(0.037)$ & $(0.075)$ & $-(0.042)$ & $(0.048)$ & $-(0.248)$ & $-(0.031)$ & $-(0.226)$ & $(0.061)$ \\
\hline & 0.254 & 0.209 & 0.324 & 0.294 & 0.150 & 0.149 & 0.148 & 0.122 & 0.343 & 0.242 & 0.239 & 0.116 \\
\hline \multirow[t]{3}{*}{ Employment } & 4895 & 3759 & 3884 & 2627 & 3593 & 2461 & 3316 & 2948 & 8885 & 7822 & 8126 & 6044 \\
\hline & $(4580)$ & $(2555)$ & $(3577)$ & (2361) & (2324) & (1393) & $(2810)$ & $(2482)$ & $(5594)$ & $(3565)$ & (2649) & (2257) \\
\hline & 2052 & 2609 & 1695 & 1037 & 2189 & 1946 & 1898 & 1687 & 10086 & 10113 & 15388 & 11035 \\
\hline \multirow[t]{3}{*}{ Debt to Asset Ratio } & 0.257 & 0.312 & 0.268 & 0.336 & 0.219 & 0.293 & 0.200 & 0.264 & 0.159 & 0.252 & 0.247 & 0.296 \\
\hline & $(0.253)$ & $(0.314)$ & $(0.266)$ & $(0.334)$ & $(0.187)$ & $(0.304)$ & $(0.186)$ & $(0.243)$ & $(0.150)$ & $(0.246)$ & $(0.203)$ & $(0.278)$ \\
\hline & 0.093 & 0.126 & 0.132 & 0.152 & 0.097 & 0.112 & 0.074 & 0.108 & 0.083 & 0.099 & 0.126 & 0.135 \\
\hline Subsidies to Sales & 0.000 & 0.000 & 0.000 & 0.000 & 0.097 & 0.000 & 0.054 & 0.000 & 0.000 & 0.000 & 0.000 & 0.000 \\
\hline \multirow[t]{2}{*}{ Ratio } & $(0.000)$ & $(0.000)$ & $(0.000)$ & $(0.000)$ & $(0.056)$ & $(0.000)$ & $(0.000)$ & $(0.000)$ & $(0.000)$ & $(0.000)$ & $(0.000)$ & $(0.000)$ \\
\hline & 0.000 & 0.000 & 0.000 & 0.000 & 0.113 & 0.000 & 0.124 & 0.000 & 0.000 & 0.000 & 0.000 & 0.000 \\
\hline Inventory to Sales & 0.180 & 0.164 & 0.208 & 0.212 & 0.115 & 0.229 & 0.127 & 0.114 & 0.175 & 0.211 & 0.167 & 0.112 \\
\hline \multirow{2}{*}{ Ratio } & $(0.166)$ & $(0.114)$ & $(0.189)$ & $(0.162)$ & $(0.102)$ & $(0.055)$ & $(0.119)$ & $(0.092)$ & $(0.155)$ & $(0.162)$ & $(0.137)$ & $(0.078)$ \\
\hline & 0.124 & 0.157 & 0.117 & 0.223 & 0.073 & 0.504 & 0.076 & 0.064 & 0.106 & 0.205 & 0.126 & 0.089 \\
\hline
\end{tabular}

(continued) 


\begin{tabular}{|c|c|c|c|c|c|c|c|c|c|c|c|c|}
\hline & \multicolumn{2}{|c|}{ Isolated Enterprises } & \multicolumn{2}{|c|}{ Control group } & \multicolumn{2}{|c|}{ Isolated Enterprises } & \multicolumn{2}{|c|}{ Control group } & \multicolumn{2}{|c|}{ Isolated Enterprises } & \multicolumn{2}{|c|}{ Control group } \\
\hline & 1992 & 1996 & 1992 & 1996 & 1992 & 1996 & 1992 & 1996 & 1992 & 1996 & 1992 & 1996 \\
\hline & \multicolumn{4}{|c|}{ Machinery and Equipment } & \multicolumn{4}{|c|}{ Road Transport } & \multicolumn{4}{|c|}{ Utilities } \\
\hline \multirow[t]{3}{*}{ Profitability } & -0.147 & -0.042 & -0.128 & 0.033 & 0.028 & 0.007 & 0.116 & -0.113 & 0.025 & -0.405 & 0.020 & -0.264 \\
\hline & $-(0.037)$ & $-(0.044)$ & $(-0.035)$ & $(0.015)$ & $(0.023)$ & $(0.030)$ & $(0.125)$ & $(-0.011)$ & $-(0.046)$ & $-(0.130)$ & $(-0.052)$ & $(-0.012)$ \\
\hline & 0.367 & 0.239 & 0.368 & 0.179 & 0.139 & 0.176 & 0.119 & 0.234 & 0.179 & 0.820 & 0.172 & 0.927 \\
\hline \multirow[t]{3}{*}{ Employment } & 5186 & 3673 & 5315 & 2955 & 8492 & 6449 & 7041 & 7854 & 77849 & 63024 & 4622 & 4822 \\
\hline & (3126) & $(2461)$ & (2463) & (1778) & (7919) & $(6155)$ & (4179) & (4179) & $(58865)$ & $(52680)$ & $(969)$ & $(544)$ \\
\hline & 4688 & 3538 & 9207 & 4447 & 6235 & 4726 & 4609 & 9656 & 88967 & 67924 & 7609 & 8908 \\
\hline \multirow[t]{3}{*}{ Debt to Asset Ratio } & 0.171 & 0.221 & 0.194 & 0.225 & 0.267 & 0.278 & 0.187 & 0.246 & 0.070 & 0.104 & 0.079 & 0.104 \\
\hline & $(0.152)$ & $(0.226)$ & $(0.167)$ & $(0.232)$ & $(0.183)$ & $(0.257)$ & $(0.199)$ & $(0.175)$ & $(0.082)$ & $(0.111)$ & $(0.062)$ & $(0.068)$ \\
\hline & 0.091 & 0.132 & 0.083 & 0.094 & 0.262 & 0.159 & 0.069 & 0.193 & 0.050 & 0.067 & 0.056 & 0.083 \\
\hline Subsidies to Sales & 0.000 & 0.000 & 0.000 & 0.000 & 0.000 & 0.000 & 0.000 & 0.000 & 0.148 & 0.273 & 0.186 & 0.199 \\
\hline \multirow[t]{2}{*}{ Ratio } & $(0.000)$ & $(0.000)$ & $(0.000)$ & $(0.000)$ & $(0.000)$ & $(0.000)$ & $(0.000)$ & $(0.000)$ & $(0.106)$ & $(0.223)$ & $(0.140)$ & $(0.084)$ \\
\hline & 0.000 & 0.000 & 0.000 & 0.001 & 0.000 & 0.000 & 0.000 & 0.000 & 0.166 & 0.270 & 0.223 & 0.298 \\
\hline Inventory to Sales & 0.329 & 0.279 & 0.262 & 0.206 & 0.079 & 0.226 & 0.031 & 0.227 & 0.000 & 0.008 & 0.002 & 0.098 \\
\hline \multirow[t]{2}{*}{ Ratio } & $(0.193)$ & $(0.271)$ & $(0.182)$ & $(0.216)$ & $(0.100)$ & $(0.215)$ & $(0.028)$ & $(0.191)$ & $(0.000)$ & $(0.007)$ & $(0.000)$ & $(0.000)$ \\
\hline & 0.337 & 0.196 & 0.303 & 0.146 & 0.060 & 0.102 & 0.030 & 0.196 & 0.000 & 0.007 & 0.006 & 0.187 \\
\hline
\end{tabular}




\section{Policy Research Working Paper Series}

\section{Title}
WPS1925 Half a Century of Development Economics: A Review Based on the Handbook of Dsvelopment Economics

\author{
Author \\ Jean Waelbroeck
}

Emmanuel Ablo

Ritva Reinikka

Fareed M. A. Hassan

June 1998

Jesko Hentschel Jean Olson Lanjouw

Peter Lanjouw

Javier Poggi

WPS1929 A Database of World infrastructure Stocks, 1950-95

WPS1930 The Main Determinants of Inflation in Albaniz

WPS1931 The Cost and Performance of Paid Agricuitural Extenion Services: The Case of Agricultural Technology

Transfer in Nicaragua

WPS1932 Air Pollution and Health Effects: A study of Respiratory lilness Among Children in Santiago, Chile

WPS1933 The 1997 Pension Reform in Mexico

WPS1934 WTO Accession for Countries in Transition

WPS1935 Explaining the Increase in Inequality during the Transition

WPS1936 Determinants of Transient and Chronic Poverty: Evidence from Rural China

WPS1937 Aid, the Incentive Regime, and Poverty Reduction

\section{David Canning}

Ilker Domac

Carlos Elbrit

Ariel Dinar

Gabriel Keynan

June 1998

June 1998

June 1998

June 1998

Bart D. Ostro

Gunnar S. Eskeland

Tarhan Feyzioglu

Jose Miguel Sanchez

Gloria Grandolini

Luis Cerda

June 1998

Constantine Michalopoulos June 1998

June 1998

Branko Milanovic

June 1998

June 1998

Jyotsna Jalan

Martin Ravallion

Craig Burnside

David Dollar

June 1998

\section{Date}

May 1998

June 1998

June 1998

Contact

for paper

J. Sweeney

31021

K. Rivera

34141

A. Panton 85433

P. Lanjouw 34529

A. Abuzid 33348

F. Lewis 82979

F. Toppin 30450

C Bernardo 31148

C. Zappala

87945

L. Tabada 36896

G. Evans 85734

P. Sader 33902

E. Khine

37471 


\section{Policy Research Working Paper Series}

Title

WPS1938 What Explains the Success

or Failure of Structural Adjustment

Programs?

\section{WPS1939 Second Thoughts on Second Moments: Panel Evidence on Asset-Based Models of Currency Crises \\ WPS1940 The Structure of Labor Markets in Developing Countries: Time Series Evidence on Competing Views}

WPS1941 Are Labor Markets in Developing Countries Dualistic?

WPS1942 Poverty Correlates and IndicatorBased Targeting in Eastern Europe and the Former Soviet Union

WPS1943 The Implications of Hyperbolic Discounting for Project Evaluation

WPS1944 Detecting Price Links in the World Cotton Market

WPS1945 Evaluating a Targeted Social Program When Placement is Decentralized

WPS1946 Estonia: The Challenge of Financial Integration

WPS1947 Patterns of Economic Growth: Hills, Plateaus, Mountains, and Plains

WPS1948 Comparative Advantage and the Cross-Section of Business Cycles

WPS1949 Education and Earnings Inequality in Mexico

WPS1950 Free Trade and Deep Integration: Antidumping and Antitrust in Regional Agreements

WPS1951 Crisis Management in Argentina during the 1994-95 Mexican Crisis: How Did Markets React?
Author

David Dollar

Jakob Svensson

Arturo J. Galindo

William F. Maloney

William F. Maloney

William F. Maloney

Christiaan Grootaert

Jeanine Braithwaite

Maureen Cropper

David Laibson

John Baffes

Martin Ravallion

Quentin Wodon

Carios Cavalcanti

Daniel Oks

Lant Pritchett

Aart Kraay

Jaume Ventura

Ulrich Lächler

Bernard Hoekman

Eduardo J. J. Ganapolsky July 1998

Sergio L. Schmukler
Date

June 1998

July 1998

Contact

for paper

E. Khine

37471

M. Cervantes 37794

M. Cervantes 37794

M. Cervantes 37794

G. Ochieng 31123

July 1998

July 1998

July 1998

Sader 33902

L. Osborne 38482

July 1998

July 1998

A. Kraay 35756

C. Lazcano 37776

L. Tabada 36896

E. Khine 37471 